\title{
Aging and nutrition. Paving the way to better health
}

\author{
EMILIO MOLINA-MOLINA ${ }^{1, *}$, GABRIELLA GARRUTI ${ }^{2, *}$, HARSHITHA SHANMUGAM $^{1, *}$, DOMENICA MARIA DI PALO $^{1}$, \\ IGNAZIO GRATTAGLIANO ${ }^{3}$, TECLA MASTRONUZZI $^{3}$, PIERO PORTINCASA $^{1}$ \\ 1 “A. Murri” Clinica Medica, Department of Biomedical Sciences \& Human Oncology, University of Bari Medical School, Bari, Italy \\ ${ }^{2}$ Department of Emergency and Organ Transplants, Section of Endocrinology, Andrology and Metabolic Diseases, \\ University of Bari Medical School, Bari, Italy \\ ${ }^{3}$ Italian College of General Practitioners and Primary Care, Florence, Italy \\ "These authors have equally contributed.
}

\begin{abstract}
Sufficient caloric intake is important to maintain the balanced health status, especially during the period of aging, as aging and sickness share paths. Maintaining adequate nutritional balance is the best preventive measure to counteract the risk of malnutrition. There are several causes for malnutrition in elderly people, and some techniques such as anthropometric measurements, laboratory and clinical parameters could help to diagnose malnutrition in these patients. The use of a simple validated questionnaire called the 'Mini Nutritional Assessment' measures the nutritional status of elderly patients. In this review, we discuss about the malnutrition in elderly people with and without a known cause and we present some of nutritional intervention. There are promising strategies that help overcoming malnutrition.
\end{abstract}

Key words: aging, anthropometric assessment, elderly, malnutrition, nutrition.

\section{INTRODUCTION}

Appropriate dietary intake is essential during aging and can increase longevity, while aging per se can increase the risk of malnutrition in older adults. During life (such as growth, chronic disable conditions or diseases), an adequate nutritional intake can help the organs by protecting the tissue trophism or retaining the autonomy and defense against outside bacteria or infections. Maintaining a correct nutrition (especially if high in protein and balanced in calories) can eventually work against the degeneration processes which accompany aging and against the development of illnesses [1].

Here, we will discuss the concepts related to nutrition with aging in the absence of particular diseases. The topic is of extreme interest especially for internists and geriatricians, since about two-third of older adults fall in the category of nutritional risk or malnutrition [2], while malnutrition is associated to the increase of mortality risk [3].

\section{GENERAL CONSIDERATIONS}

In general, the term "malnutrition" encompasses two extreme conditions, namely undernutrition, as well as overweight and obesity [4].

Malnutrition intended as undernutrition is characterized by deficient nutritional status, inadequate dietary intake and use of nutrients which lead to change in quality of life, high rate of morbidity and mortality [5]. Undernutrition paves the way to various health concerns, which include a defective immune system, risk of infections, poor skeletal muscle mass, osteoporosis, and predisposition to bone fractures and other complications.

Malnutrition intended as being overweight or obese, on the other hand, predisposes to several cardiovascular complications such as coronary heart diseases, heart failure or sudden death, and metabolic disorders. Not only cardiovascular, but also respiratory (such as obstructive sleep apnea or hypoventilation) as well as osteo-articular diseases can be impaired by this pathological condition [6]. However, the impact of obesity in the elderly remains largely unexplored. This aspect is of particular relevance to address strategies able to decrease the impact of obesity on disability and health-related quality of life [7]. Disability is present ten years earlier in overweight/ obese people than in people with normal weight, and most obese/overweight subjects will also suffer from disability at a later age [8]. However, one should also consider the so-called "obesity paradox" (i.e. the potential protective effect of overweight against mortality and the negative effect of underweight) [9].

Thus, specific and adequate interventional models and guidelines in elderly people must be carefully balanced against specific risks of underweight and undernutrition versus overweight and obesity and comorbidity risks [10]. 


\section{MALNUTRITION (UNDERNUTRITION) IN OLDER ADULTS}

The physiological process of aging includes a general decrease of body functions and a less efficient immunological system. Both conditions are associated with systemic inflammation ('inflammaging'). This scenario points to the fragility of elderly people, who become more prone to several pathological issues. The general picture includes decreased gastrointestinal secretions and motility, and decreased nutrient absorption. Decreased saliva secretion (xerostomia) and gastric $\mathrm{HCl}$ secretion (due to progressive mucosal atrophy) are two examples of this progressive intestinal mucosa atrophy. In addition, decreased iron and vitamin B12 absorption may occur with age. Food intake might also decrease due to progressive decrease of caloric requirement and malabsorption. Hormonal pathways are also involved in this respect, including decreased secretion of gastrointestinal hormones such as ghrelin and cholecystokinin. Other actors are decreased taste and smell, as well as lifestyle changes, depending on aging. Additional factors include social environment, economic conditions, body composition changes, decreased lean mass (sarcopenia), and increased fat mass due to sedentary life. Furthermore, these additional factors might depend on ongoing specific diseases such as atrophic gastritis, the use of nonsteroidal anti-inflammatory drugs (NSAIDs) or intestinal atrophic changes. NANHES studies suggest that elderly people are therefore prone to protein malnutrition, anemia, vitamin, mineral and calcium deficiencies, and changes of intestinal permeability. Clinical pictures might also include topographic, qualitative and quantitative changes of microbial distribution in the intestine (i.e. small intestinal bacterial overgrowth, decreased Bifidobacteria or Faecalibacterium prausnitzii and increased Proteobacteria). Changes might result in decreased ability to synthesize short-chain fatty acids.

Several aspects of microbiota change during aging might be dictated by changes of gut-associated lymphoid issue, leading to decreased activation of natural killer immunological cells and lymphocytes $\mathrm{T}$ response, progressive timus atrophy, and increased secretion of pro-inflammatory systemic cytokines.

Malnutrition often occurs in elderly people and becomes a serious complication. Clinicians are paying a lot of attention to protein-caloric malnutrition, which is increasing drastically in Western societies and rises with age and sex [1]. In older adults, the prevalence of malnutrition was $23 \%$ in one study across Europe, USA, and South Africa [11]. Prevalence differs since malnutrition occurs in about $5-12 \%$ of people leaving at home, in $26-65 \%$ of hospitalized patients, and up to $85 \%$ of those living in health residences [12-15]. The wide range of reported prevalence can also depend on different definition criteria of malnutrition, diagnosis, and settings.

\section{CAUSES OF MALNUTRITION}

Nutritional support in elderly is dependent on several causes, which include age-related organic conditions, disease-related conditions, and/or social, environmental and physiological conditions (Figure 1).

Even though protein-caloric malnutrition is a major issue for overall health status of elderly people, physicians and health workers often miss this condition [16-19]. In contrast, the early recognition of malnutrition reduces the negative consequences and is part of support strategies, including nutritional supplementation with personalized treatment plans [17-20]. Malnutrition as a marker of disease severity in elderly people appears in Table 1. Early diagnosis of malnutrition in elderly people is important, since effects of malnutrition are associated with both morbidity and mortality [21], physical function [22], use of health care resources [23], and length of hospital stay $[24,25]$. In previously undernourished patients, a weight increase of at least $5 \%$ of body weight is associated with a decreased incidence of death. Morbidity events appear also to decrease [26].

Frail elderly individuals show a progressive impairment of the ability to feed autonomously and adequately. Elderly people experience less frequent hunger than younger adults and defective adaptation to underfeeding, with poorer weight recovery [27].

Some causes of malnutrition are closely associated to aging itself, such as atrophy of the oral mucosa and tongue with altered/decreased taste/ odor perception [28], edentulism with effects on chewing [29], delayed gastric emptying (leading to increased satiety) [30], reduced gastric and pancreatic secretion with impaired digestion, and absorption of nutrients. Age-dependent visual brilliance, joint problems and shiver in the hands, are additional event. Dysphagia has a prevalence of $7-10 \%$ in older patients but can increase dramatically, up to $50 \%$ in patients after a stroke episode or Parkinson disease [31-34]. The risk of dysphagia can increase due to reduced alertness. Some hormones, like glucagon-like peptide-1 (GLP-1), glucagon, cholecystokinin (CCK), leptin, and ghrelin act as peripheral satiety signals. During aging these hormones are less well-detected by the brain [35]. Impaired hormonal function might therefore affect the regulation of food intake in elderly people. 


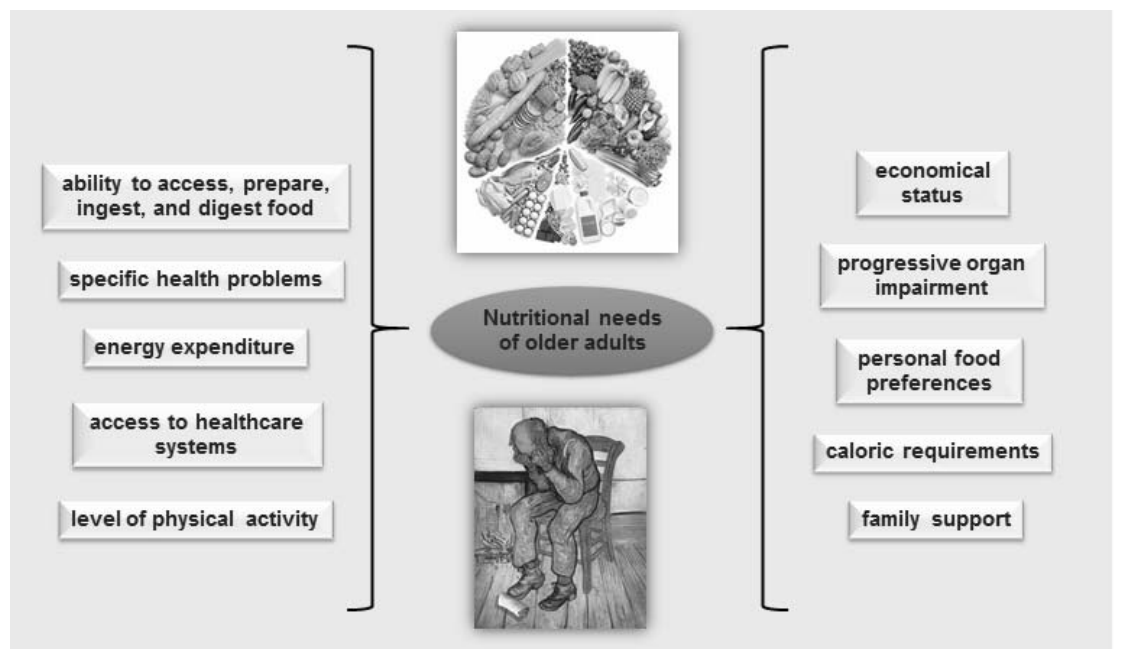

Figure 1. Factors governing nutritional needs of older adults.

Table 1

Malnutrition as an indicator of disease severity in elderly

\begin{tabular}{|l|l|c|}
\hline \multicolumn{1}{|c|}{ OUTCOME } & \multicolumn{1}{|c|}{ IMPACT OF MALNUTRITION } & REFERENCES \\
\hline Morbidity & $\begin{array}{l}\text { - Independent risk factor together with hospital readmission } \\
\text { - Increases prevalence of morbidity to } 48 \% \text { in malnourished patients undergoing elective } \\
\text { surgery for non-neoplastic causes } \\
\text { - Affects depression and cognitive performance }\end{array}$ & {$[127,128]$} \\
\hline Hospitalization & $\begin{array}{l}\text { - Inversely related to nutritional status in elderly women with hip fracture } \\
\text { - Direct association between malnutrition and post-surgical mobility recovery in women } \\
\text { - Double time of recovery in non-neoplastic subjects when malnourished }\end{array}$ & {$[129,130,24,25]$} \\
\hline Mortality & $\begin{array}{l}\text { - Related to anthropometric, biochemical, immunological, functional or underlying } \\
\text { conditions (body weight change and albumin levels most predictive) } \\
\text { - Mortality is five times greater in malnourished women hospitalized for hip fracture }\end{array}$ & {$[131,132,130]$} \\
\hline Costs & $\begin{array}{l}\text { - Increased costs across Europe (>120€ billion annually) } \\
\text { - Almost double than obesity management }\end{array}$ & {$[133-135,13]$} \\
\hline
\end{tabular}

Further medical conditions (cardiovascular, gastrointestinal, infective, rheumatologic, and neurologic), may also affect the prevalence of dysphagia as a contributing factor to weight loss. The presence of malignancy [36], especially of the gastrointestinal tract [37] is an important cause of weight loss.

Among psychological factors, one should include depression, as well as dysphoria, especially in the subacute care, nursing home context, and community in older patients [36].

Use of drugs and/or polytherapy may affect body weight. Antacids and laxatives, diuretics, sedatives, digoxin, serotonin-reuptake inhibitors, opioids, topiramate, may interfere with gastric absorption, renal function, and alter taste perception.

Social risk factors include loneliness and decreased calorie intake [38, 39], financial limitations/ poverty, isolation, and institutionalization $[12,40]$.

Further components of malnutrition and unintentional weight loss also include:

- Anorexia is appetite loss. This condition can be physiological, due to simple age-dependent and adaptive decrease of food intake/calories [41], taste changes etc., or specific diseases [42].

- Cachexia (inflammatory effects of disease associated to muscle loss with or without fat mass loss) [43]. Can be associated also with anorexia, insulin resistance, and inflammation. Can be resistant to nutritional interventions, due to its multifactorial origin, especially cytokine-mediated response (i.e. interleukin (IL)-1, TNF-alpha (TNF-a), IL-6 [44-46]. Known predisposing factors to cachexia include neoplasms, chronic pulmonary disease, rheumatoid arthritis, end-stage renal disease, heart failure, and acquired immunodeficiency syndrome (AIDS). Mechanisms leading to myofibrillar breakdown include the ubiquitin proteasome pathway, as well as cortisol and adrenergic hormones activating fat oxidation, insulin resistance, fatigue [47].

- Sarcopenia (loss of muscle mass, strength and performance) [48-50]. Sarcopenia occurs independently of an underlying illness and is not necessarily associated with cachexia. Low muscle mass in sarcopenic patients can be assessed by DEXA or bioelectrical impedance. Causes of sarcopenia include 
disuse, hormonal changes, chronic diseases, insulin resistance [51], inflammation, decreased physical activity $[52,53]$, as well as nutritional deficiencies [48] including decreased protein intake [54].

The prevalence of sarcopenia can be as high as $57-60 \%$ in both males and female over the age of 80 [55]. Sarcopenia with decreased muscle strength is also found in sarcopenic-obese [56], but also in normal and underweight individuals.

The elderly people may develop alcoholrelated problems, and risk factors for alcohol abuse include a prior history of alcohol use, grief, anxiety, depression, pain, and disability. This issue is of key importance since alcohol dependence can be associated with inadequate dietary intake and malnutrition. Subjects at risk should be questioned about frequency and quantity of alcohol use, using CAGE questions. [57, 58] or a variety of available tools [59]. Epidemiological studies show that about $50 \%$ of adults aged more than 65 consume alcohol. A considerable group (about 15\%) drink more than the dose allowed, i.e. more than seven drinks per week. In addition, more than $50 \%$ of older drinkers display hazardous consumption of alcohol [60], Elderly people having problematic alcohol consumption are at risk of impaired function, cognition, falls and general health.

\section{DIAGNOSIS OF MALNUTRITION}

\section{A. Identification of at-risk individuals for malnutrition}

The definition of malnutrition has followed since 2012 the Guidelines from the Academy of Nutrition and Dietetics (Academy) and the American Society for Parenteral and Enteral Nutrition (ASPEN) requires at least two out of six conditions to be present for the diagnosis of malnutrition [61] (Table 2).

The emerging role of acute and chronic inflammation and its impact on malnutrition was subsequently appreciated by the Global Leadership Initiative on Malnutrition (GLIM) [62], which require both phenotype and etiologic criteria to be present (Table 2).

Table 2

Diagnosis of malnutrition (undernutrition)

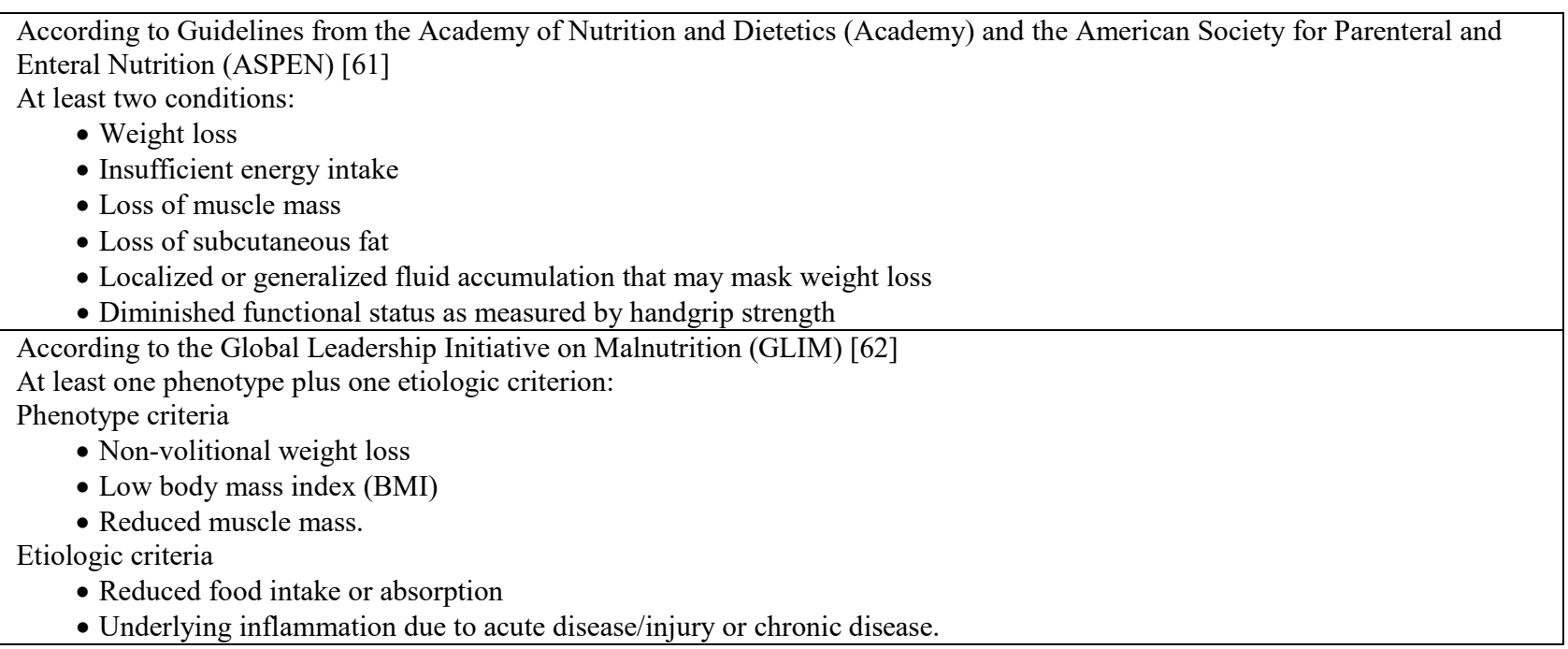

Anthropometric measurements are important diagnostic tools to determine the distribution of fat and proteins in the body. The assessment is safe, easy to perform, reproducible, quick and affordable [63]. Measurements include weight, height, hip circumferences, and thickness of subcutaneous skinfolds, legs and abdomen. In elderly people, however, anthropometric measurements are difficult in bedridden patients or with ongoing conditions such as edema or compartmentalized fluids (i.e. ascites, pleural and cardiac effusions).

Weight is the first measurement, and low body weigh occurs with less of $80 \%$ of the recommended body weight, according to specific tables for elderly people.

Weight loss is another important measurement in older adults, especially when is not volitional, and because weight loss predicts mortality [64, 65, 3]. Among community-dwelling older adults, even a loss of $5 \%$ of weight over a 3 -year period is linked to increased mortality [66]. Weight loss becomes clinically relevant when $\geq 2 \%, 5 \%, 10 \%$ of baseline body weight in 1, 3, and 6 months respectively [67]. In patient living in the long-term care setting, weight-loss becomes clinically significant with a loss of $5 \%$ or $10 \%$ of usual body weight in 1 or 
6 months, respectively [68]. The initial evaluation of weight loss should include the recording of changes, bioelectrical impedance, mid-upper- or mid-arm circumference, appetite and dietary intake, blood analyses (including glucose and electrolytes, thyroid-stimulating hormone (TSH), complete blood count (CBC), and C-reactive protein (CRP), serum albumin). Other investigations may include chest and abdominal radiographs [69], thoracic, abdominal, pelvic computed tomography (CT), magnetic resonance imaging (MRI), and endoscopic procedures, depending on single cases. Multidimensional screening tools should be part of such evaluation (see below).

\section{B. Assessment of nutritional status in at-risk individuals}

In elderly people, the measurement of body mass index (BMI) might not be very informative when searching for malnutrition. BMI is calculated as the Quetelet's index (i.e. kilograms divided by meter squared, $\mathrm{kg} / \mathrm{m}^{2}$ ). Subjects are therefore classified as underweight $\left(<18.5 \mathrm{~kg} / \mathrm{m}^{2}\right)$, normal weight $\left(\geq 18.5 \mathrm{~kg} / \mathrm{m}^{2}\right.$ and $\left.<25 \mathrm{~kg} / \mathrm{m}^{2}\right)$, overweight $\left(\geq 25 \mathrm{~kg} / \mathrm{m}^{2}\right.$ and $\left.<30 \mathrm{~kg} / \mathrm{m}^{2}\right)$ and obesity $\left(\geq 30 \mathrm{~kg} / \mathrm{m}^{2}\right)[70]$.

Data discussed so far need to be harmonized with further considerations. In older adults, weight loss is more dangerous for those with a BMI below $30 \mathrm{Kg} / \mathrm{m}^{2}$ (greater mortality threat) than for those with a BMI 25-30 Kg/m2 [71]. Obesity, however, is associated with increased morbidity and mortality in older adults. There is a link between extreme BMIs (i.e., very low or very high) and increased risk of death [72]. Intentional weight loss with exercise in these patients brings beneficial effects. This is particularly true in the presence of other conditions, such as diabetes mellitus, coronary heart disease osteoarthritis, and impaired activity tolerance [73-75].

Waist circumference, by contrast, provides a better basis for evaluation of obesity in aging populations [76].

To quantify and diagnose malnutrition, some clinical and laboratory tests could help, too [77]. The lean body mass of the patient can be determined by using the creatinine-height index [(measured urinary creatinine $\times 100$ )/ ideal urinary creatinine for a given height].

The severity of malnutrition and nutritional status is associated with the levels of some plasma proteins (Table 3). Serum albumin is used to assess changes in dietary protein intake, kidney function and other inflammatory conditions. Transferrin has a shorter half-life and is a measure of protein deposit, while prealbumin has an even shorter halflife and is a marker of reserve of proteins.

Table 3

Characteristics of plasma proteins

\begin{tabular}{|l|l|l|}
\hline \multicolumn{1}{|c|}{ Protein } & \multicolumn{1}{|c|}{ Half-life } & \multicolumn{1}{c|}{ Information } \\
\hline Serum albumin & Long & $\begin{array}{l}\text { - Changes in dietary protein intake } \\
\text { - Predictor of chronic kidney disease } \\
\text { - Other conditions: inflammation, acute or chronic stress, overhydration, urinary or peritoneal } \\
\text { losses, and acidemia }\end{array}$ \\
\hline Transferrin & Short (8 days) & $\begin{array}{l}\text { - Depletion of protein deposit } \\
\text { - Nutritional status } \\
\text { - Correlation with clinical outcomes }\end{array}$ \\
\hline Prealbumin & $2-3$ days & $\begin{array}{l}\text { - Reserve of proteins } \\
\text { - Nutritional status }\end{array}$ \\
\hline
\end{tabular}

Together, these proteins help in the assessment of nutritional status in elderly patients.

Indirect methods also indicate malnutrition in patients, and include the complete number of circulating lymphocytes (abnormal when less of 1,500 cells $/ \mathrm{mm}^{3}$ ). The delayed-type hypersensitivity skin testing is based on the reaction that occurs in response to the intradermal injection of an antigen (i.e. tuberculin, candida albicans, histoplasmin, etc.). Other serum biomarkers are much less informative and helpful to assess the nutritional status or to plan nutritional intervention [77].

Multidimensional screening tools can help in the evaluation of malnutrition and include:
1. Prognostic Nutritional Index (PNI) is based on serum albumin, serum transferrin, triceps skinfold and the delayed-type hypersensitivity skin testing [78].

2. Geriatric Nutritional Risk Index (GNRI) helps in diagnosing weight, weight loss, and serum albumin [79].

3. Malnutrition Universal Screening Tool (MUST) can assess weight, height, weight loss (in 3 to 6 months) and acute diseases $[80,81]$.

4. Nutrition Risk Screening (NRS) measures weight, height, weight loss, acute diseases and reduced caloric intake [82]. Disease severity ranges from 0 score (patients with chronic illnesses or a hip fracture) 
to 3 (patients in the intensive care unit with an APACHE score of 10).

5. Malnutrition Screening Tool (MST) in acutely hospitalized patients and cancer patients. The tool relies on two simple questions, i.e., "Have you been eating poorly because of a decreased appetite?" and "Have you lost weight recently without trying?" Sensitivity is $74-100 \%$ in hospitalized patients and specificity is $76-93 \%$, compared with Subjective Global Assessment [83].

6. Mini Nutritional Assessment (MNA) relies on subjective perception of health. MNA is the most widely used non-invasive, cost-effective tool to assess the nutritional status in elderly patients. Questions investigate diet and some body measurements, and MNA is predictive of poor outcomes [84-86]. The Short Form version (MNA-SF) is based on 6 questions from MNA (A to F1/F2) [87] and is used to extract information about the risk of malnutrition in a very fast and practical way. A score appears at the end [87]. The tool incorporates calf circumference instead of BMI, if not measurable [88] (Table 4) [87, 89-91]. The test is recommended by the European Society of Parenteral and Enteral Nutrition [82], the Programme National Nutrition Santé [92], and in Italy by the guidelines for the assessment of malnutrition in the elderly [21]. The specificity and sensitivity of this test is $98 \%$ and $96 \%$ respectively, in detection of malnutrition [87]. The complete test version is available online [Nestle Nutrition Institute, mna-elderly.com], and is validated against other anthropometric and biochemical markers [87], hence making the test reliability to 0.89 [93]. MNA is inversely related to both length of stay in hospital and hospital services $[94,95]$, and has been validated in different populations including Spanish [96], American [91], Australian [97], Korean [98], Italian [99], Estonian [100], Taiwan [101], Finnish [102], Japanese [103], Chilean [104] and Brazilian [105]. MNA also predicts the long- and short-term mortality and morbidity in hospitalized patients [106]. The MNA short form is reliable also in General Practice [13].

\section{Table 4}

\section{Mini Nutritional Assessment - short form}

Questions

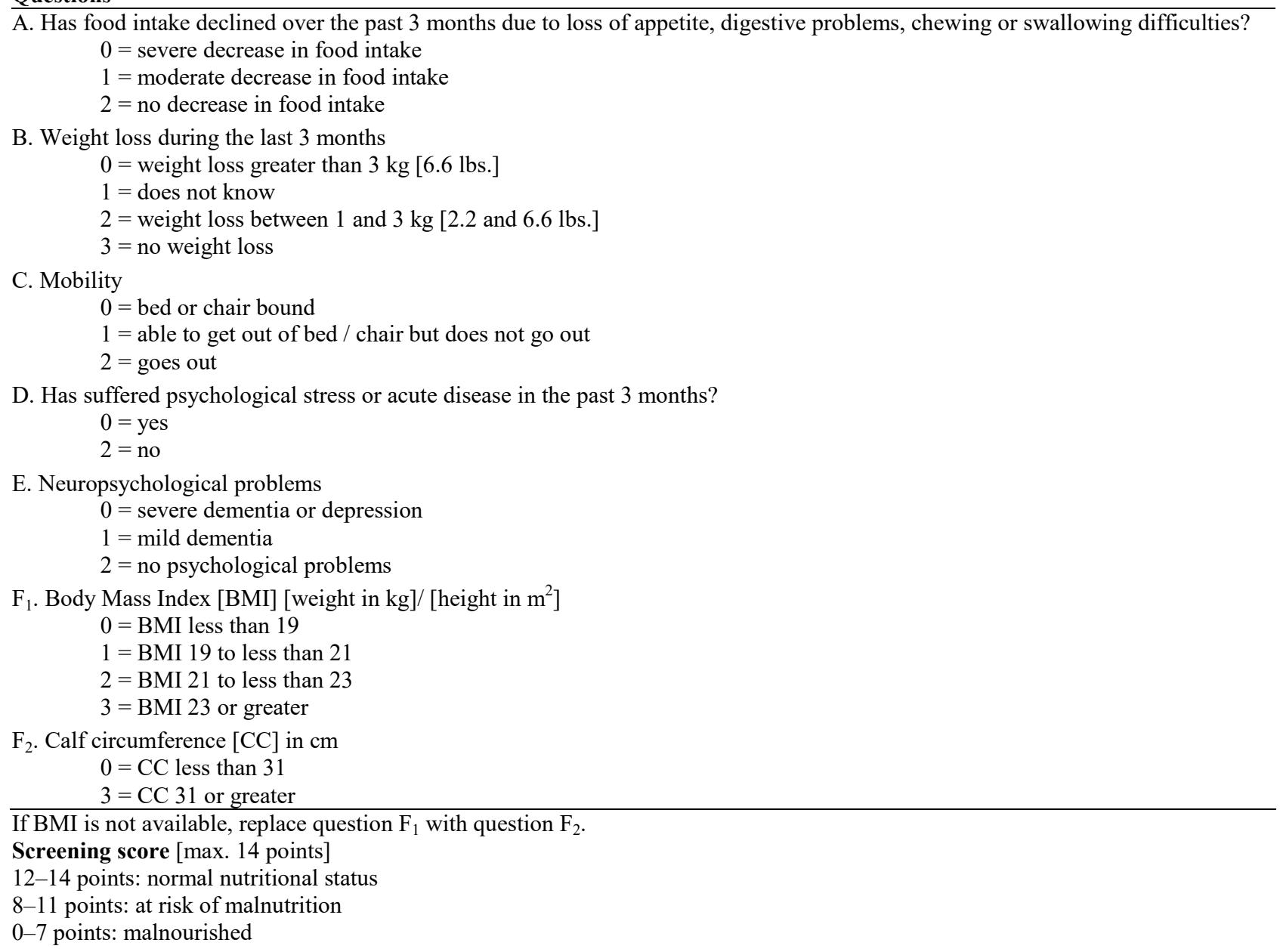




\section{NUTRITIONAL INTERVENTION IN ELDERLY}

During the process of aging, elderly people lack nutrients, which are required for their body metabolism; this could be fulfilled by nutritional interventions. The concept is to supply adequate necessary nutrients either by dietary, pharmacological or artificial strategies to prevent malnutrition combined with protein and non-protein calories [107, 108]. Appropriate healthy food pyramids for older adults exist [109], which emphasize the need of regular physical activity and social interaction, fluid intake, and balanced vegetable, fruit, cereals, animal proteins, fats, along with vitamins and calcium (Figure 2). The main aim of nutritional intervention is to reduce the mortality and morbidity, improve the quality of life and improve the physical performance by providing sufficient energy, macronutrients, and micronutrients [110]. Secondary causes of malnutrition must be adequately identified and treated, whenever possible, also following the acronym "MEALS ON WHEELS" (Table 5) by Morley JE [111]. Interventions in the malnourished patient should follow appropriate indications for calorie and protein requirements. In particular, Recommended Dietary Allowance (RDA) for protein is $0.80 \mathrm{~g} / \mathrm{kg}$ body weight/day for adults $\geq 51$ years old of both sexes [112]. Interfering and useless dietary restrictions should be corrected [113]. Feeding or shopping assistance should be available [114], while the choice of foods should follow each individual taste.

The nutritional intervention is proposed for a higher period in elderly patients when compared to the younger patients, often to eradicate the malnutrition and to maintain a stable functioning of the body. Soon after establishing the diagnosis of the malnutrition, natural feeding is the next step, to balance the nutrients and to enhance the protein intake according to nutritional recommendation and use of supplements.

\section{Food pyramid for older adults}

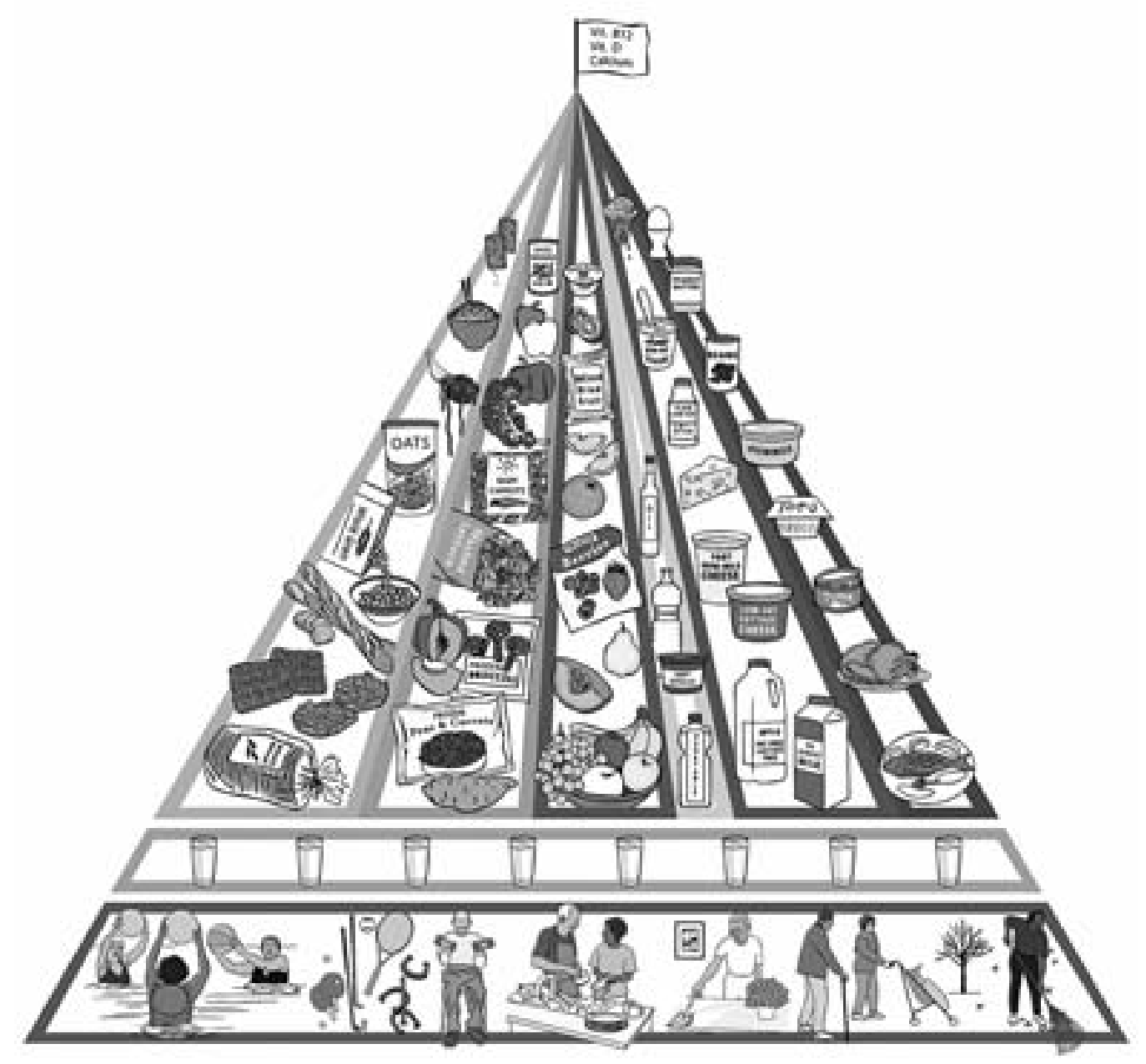

Figure 2. Food pyramid for older adults [109]. With permission from LICHTENSTEIN, A.H. RASMUSSEN, H. YU, W.W. EPSTEIN, S.R. \& RUSSELL R.M., 2008. Modified MyPyramid for Older Adults. The Journal of Nutrition, 138, 5-11. 
Table 5

Causes of weight loss in older adults (acronym "MEALS ON WHEELS")

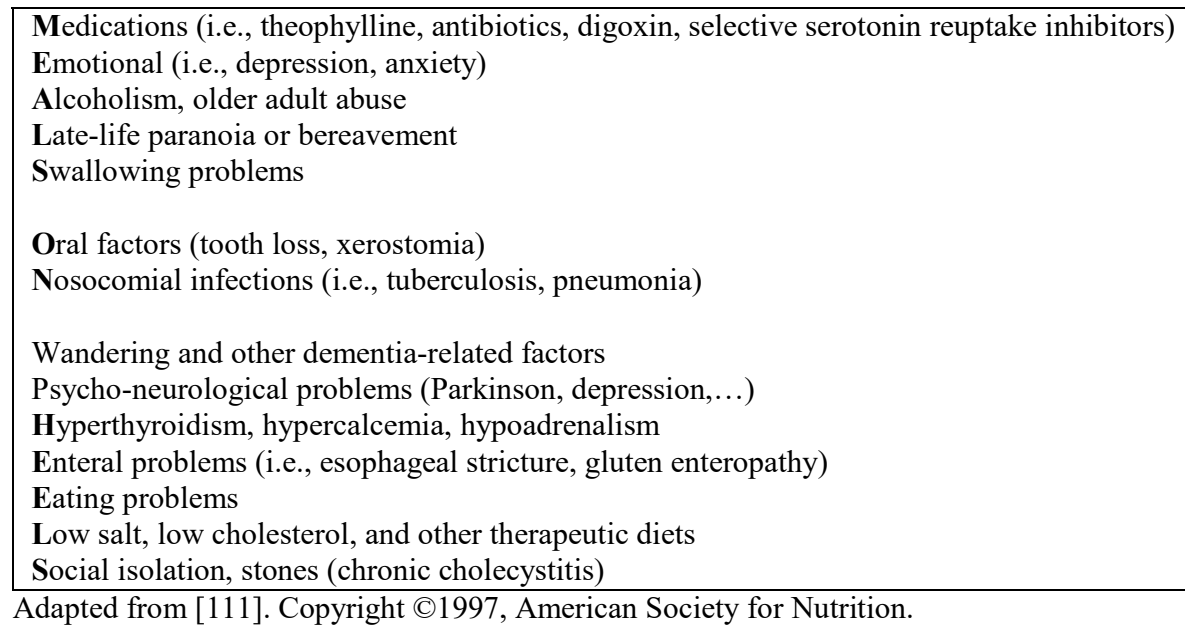

The oral supplementation of nutrients covers most of the nutritional need from macronutrient intake (Table 6). There are many supplements available in the market with different flavor and texture to help elderly patients in different conditions. However, such supplements fail when severity of the disease increases and supplementation is required through nasogastric tube or gastrostomy. The role of such supplements is doubtful when considering survival in frail patients $[115,116]$. In patients with depression, the caloric integration improves the overall health status [107]. Moreover enteral nutrition by means of oral nutritional supplements and tube feeding increases nutrient intake if oral food intake is insufficient. Due to the nutritional deficiency in elderly patients after major surgery or fractures, protein supplements is recommended. This approach decreases the risk of complications. Patients with risk of pressure from ulcers are treated together with preventive measures and additional nutritional therapy [117]. Protein support contribute to reduce the risk of pressure from ulcers developed during the healing process [118]. To stimulate the tissue repair, a nutritional intervention enriched with glutamine, arginine, $\beta$-hydroxyl- $\beta$-methyl butyrate (HMB), and zinc is better than a standard nutritional treatment. Well-balanced mixture of oral amino acids exist which stimulate the muscle protein synthesis and mitochondrial ATP production in cases of scarcity, and these have been effectively tested in patients of different metabolic conditions [119-121].

Table 6

Treatment of weight loss in older adults

\begin{tabular}{|l|l|}
\hline \multirow{3}{*}{ Nutritional supplements } & $\begin{array}{l}\text { - Daily multivitamin and mineral supplement for a better physical performance and strength [136] } \\
\text { - Protein and amino acids supplement to tackle undernourishment and sarcopenia [137-139] } \\
\text { - Liquid dietary supplement }\end{array}$ \\
\hline $\begin{array}{l}\text { - Megestrol acetate for weight gain in anorexia and cachexia patients [140-142] } \\
\text { Appetite stimulants }\end{array}$ & $\begin{array}{l}\text { - Dronabinol to improve appetite in patients with AIDS [143] } \\
\text { - Mirtazapine for management of weight loss in Alzheimer disease patients [144] } \\
\text { - Ghrelin mimetics (growth hormone secretagogues) to increase fat-free mass [145] }\end{array}$ \\
\hline
\end{tabular}

$\mathrm{HMB}$, an amino acid leucine metabolite [122] is a safe therapy and nutritional supplement in elderly patients with muscular atrophy and pressure ulcers $[123,124]$. Leucine, on the other hand, is a regulator of protein metabolism and provides an anti-catabolic activity [125]. This effect, in turn, counteracts muscle atrophy due to inactivity [126]. Medications could represent an option in subgroup of patients (Table 6), and they may include orexigenic drugs (i.e., appetite stimulants), such as dronabinol, mirtazapine, growth hormone secretagugues, megestrol acetate.

\section{CONCLUSIONS}

Nutritional balance in elderly patients plays a crucial role, as it involves the maintenance of adequate health status. Adequate nutritional intake 
provides maintenance of a strong immune system response, protecting subjects from infectious diseases, organ dysfunctions, and contributing to health status, and better quality of life. During aging, an early assessment of the nutritional status is vital to prevent/delay the severity of diseases, especially during disabling conditions, and should be proposed periodically. Early diagnosis of malnutrition could be an indicator of morbidity and mortality in frail people. On the other hand, adequate nutritional support with amount of microand macronutrients helps improving the health status of elderly. This policy might be one of the best strategies to reduce mortality and morbidity, and to maintain the nutritional status and physical performance. However, the inaccurate assessments of the nutritional status may result in an underestimation of the impact of obesity on morbidity and mortality in elderly people leading to poor evaluation of the health status. Accurate knowledge of the changes in body composition and fat distribution will help to better understand the relationship between obesity, morbidity, and mortality in the elderly. On the other hand, inadequate interventions (i.e. rapid weight loss, unbalanced diet) aimed at treating obesity in aged people should be carefully proposed to avoid negative consequences.

Aportul caloric suficient este important pentru a menţine starea de sănătate mai ales în timpul bătrâneții având în vedere că înaintarea în vârstă se asociază cu morbiditatea. Menţinerea unei balanţe adecvate este cea mai bună măsură preventivă pentru contracararea riscurilor malnutriţiei. Există mai multe cauze ale malnutriţiei la pacienţii vârstnici, iar pentru diagnosticarea acesteia sunt disponibile măsurătorile antropometrice şi diverse teste de laborator. Folosirea unui chestionar simpul de administrat denumit „Mini Nutritional Assessment” măsoară statusul nutriţional la pacienţii vârstnici. În acest articol sunt discutate aspecte ale malnutriţiei la vârstnici şi sunt prezentate anumite intervenţii nutriţionale. In prezent există strategii promiţătoare care ajută la prevenirea malnutriţiei.

Correspondence to: Piero Portincasa, Internist, PhD, Dr. H.C., AGAF, “A. Murri” Clinica Medica, Department of Biomedical Sciences and Human Oncology, 'Aldo Moro' University of Bari, Italy;

Tel.: +39-080-547-8893;

E-mail: piero.portincasa@uniba.it.

Conflict of interest disclosure: None to declare.

Funding: The present chapter is written in the context of the project FOIE GRAS, which has received funding from the European Union's Horizon 2020 Research and Innovation programme, under the Marie Skłodowska-Curie Grant Agreement (\#722619, Emilio Molina-Molina and Harshitha Shanmugam are recipients of 'Foie Gras' Early Research Training Grants).

\section{REFERENCES}

1. CHENG W.H., BOHR V.A., DE CABO R., Nutrition and aging, Mech Ageing Dev., 2010, 131: 223-4.

2. DE LUIS D., LOPEZ GUZMAN A., NUTRITION GROUP OF SOCIETY OF C-L., Nutritional status of adult patients admitted to internal medicine departments in public hospitals in Castilla y Leon, Spain - A multi-center study, Eur. J. Intern. Med., 2006, 17: 556-60.

3. WALLACE J.I., SCHWARTZ R.S., LACROIX A.Z., UHLMANN R.F., PEARLMAN R.A., Involuntary weight loss in older outpatients: incidence and clinical significance, J. Am. Geriatr. Soc., 1995, 43: 329-37.

4. World Health Organization. What is malnutrition?, 2016.

5. CEDERHOLM T., BOSAEUS I., BARAZZONI R., BAUER J., VAN GOSSUM A., KLEK S. et al., Diagnostic criteria for malnutrition - An ESPEN Consensus Statement, Clin. Nutr., 2015, 34: 335-40.

6. POIRIER P., GILES T.D., BRAY G.A., HONG Y., STERN J.S., PI-SUNYER F.X. et al., Obesity and cardiovascular disease: pathophysiology, evaluation, and effect of weight loss: an update of the 1997 American Heart Association Scientific Statement on Obesity and Heart Disease from the Obesity Committee of the Council on Nutrition, Physical Activity, and Metabolism, Circulation, 2006, 113: 898-918.

7. INELMEN E.M., SERGI G., COIN A., MIOTTO F., PERUZZA S., ENZI G., Can obesity be a risk factor in elderly people?, Obes. Rev., 2003, 4: 147-55. 
8. FERRARO K.F., SU Y.P., GRETEBECK R.J., BLACK D.R., BADYLAK S.F., Body mass index and disability in adulthood: a 20-year panel study, Am. J. Public. Health., 2002, 92: 834-40.

9. BOSELLO O., VANZO A., Obesity paradox and aging, Eat. Weight. Disord., 2019.

10. VERONESE N., CEREDA E., SOLMI M., FOWLER S.A., MANZATO E., MAGGI S. et al., Inverse relationship between body mass index and mortality in older nursing home residents: a meta-analysis of 19,538 elderly subjects, Obes. Rev., 2015, 16: $1001-15$.

11. KAISER M.J., BAUER J.M., RAMSCH C., UTER W., GUIGOZ Y., CEDERHOLM T. et al., Frequency of malnutrition in older adults: a multinational perspective using the mini nutritional assessment, J. Am. Geriatr. Soc., 2010, 58: 1734-8.

12. CONSTANS T., Malnutrition in the elderly, Rev. Prat., 2003, 53: 275-9.

13. MASTRONUZZI T., PACI C., PORTINCASA P., MONTANARO N., GRATTAGLIANO I., Assessing the nutritional status of older individuals in family practice: Evaluation and implications for management, Clin. Nutr., 2015, 34: 1184-8.

14. GUIGOZ Y., VELLAS B., GARRY P.J., Assessing the nutritional status of the elderly: The Mini Nutritional Assessment as part of the geriatric evaluation, Nutr. Rev., 1996, 54: S59-65.

15. CEREDA E., PEDROLLI C., KLERSY C., BONARDI C., QUARLERI L., CAPPELlO S. et al., Nutritional status in older persons according to healthcare setting: A systematic review and meta-analysis of prevalence data using MNA((R)), Clin. Nutr., 2016, 35: 1282-1290.

16. ROLLAND Y., PERRIN A., GARDETTE V., FILHOL N., VELLAS B., Screening older people at risk of malnutrition or malnourished using the Simplified Nutritional Appetite Questionnaire (SNAQ): a comparison with the Mini-Nutritional Assessment (MNA) tool, J. Am. Med. Dir. Assoc., 2012, 13: 31-4.

17. ARTAZA-ARTABE I., SAEZ-LOPEZ P., SANCHEZ-HERNANDEZ N., FERNANDEZ-GUTIERREZ N., MALAFARINA V., The relationship between nutrition and frailty: Effects of protein intake, nutritional supplementation, vitamin D and exercise on muscle metabolism in the elderly. A systematic review, Maturitas, 2016, 93: 89-99.

18. BONNEFOY M., BERRUT G., LESOURD B., FERRY M., GILBERT T., GUERIN O. et al., Frailty and nutrition: searching for evidence, J. Nutr. Health. Aging, 2015, 19: 250-7.

19. HOLMES S., Barriers to effective nutritional care for older adults, Nurs. Stand., 2006, 21: 50-4.

20. HUDGENS J., LANGKAMP-HENKEN B., The Mini Nutritional Assessment as an assessment tool in elders in long-term care, Nutr. Clin. Pract., 2004, 19: 463-70.

21. GUYONNET S., ROLLAND Y., Screening for Malnutrition in Older People, Clin. Geriatr. Med., 2015, 31: $429-37$.

22. SHEN H.C., CHEN H.F., PENG L.N., LIN M.H., CHEN L.K., LIANG C.K. et al., Impact of nutritional status on long-term functional outcomes of post-acute stroke patients in Taiwan, Arch. Gerontol. Geriatr., 2011, 53: e149-52.

23. BAUMEISTER S.E., FISCHER B., DORING A., KOENIG W., ZIERER A., JOHN J. et al., The Geriatric Nutritional Risk Index predicts increased healthcare costs and hospitalization in a cohort of community-dwelling older adults: results from the MONICA/KORA Augsburg cohort study, 1994-2005, Nutrition, 2011, 27: 534-42.

24. LELli D., CALLE A., PEREZ L.M., ONDER G., MORANDI A., ORTOLANI E. et al., Nutritional Status and Functional Outcomes in Older Adults Admitted to Geriatric Rehabilitations: The SAFARI Study, J. Am. Coll. Nutr., 2019, 38: 441-446.

25. LEANDRO-MERHI V.A., DE AQUINO J.L., SALES CHAGAS J.F., Nutrition status and risk factors associated with length of hospital stay for surgical patients, JPEN J. Parenter. Enteral. Nutr., 2011, 35: 241-8.

26. KELLER H.H., Weight gain impacts morbidity and mortality in institutionalized older persons, J. Am. Geriatr. Soc., 1995, 43: 165-9.

27. ROBERTS S.B., Regulation of energy intake in relation to metabolic state and nutritional status, Eur. J. Clin. Nutr., 2000, 54(3): S64-9.

28. ROLLS B.J., Do chemosensory changes influence food intake in the elderly?, Physiol. Behav., 1999, 66: 193-7.

29. RITCHIE C.S., JOSHIPURA K., SILLIMAN R.A., MILLER B., DOUGLAS C.W., Oral health problems and significant weight loss among community-dwelling older adults, J. Gerontol. A Biol. Sci. Med. Sci., 2000, 55: M366-71.

30. HOROWITZ M., MADDERN G.J., CHATTERTON B.E., COLLINS P.J., HARDING P.E., SHEARMAN D.J., Changes in gastric emptying rates with age, Clin. Sci. (Lond), 1984, 67: 213-8.

31. ACHEM S.R., DEVAULT K.R., Dysphagia in aging, J. Clin. Gastroenterol., 2005, 39: 357-71.

32. MANN G., HANKEY G.J., CAMERON D., Swallowing disorders following acute stroke: prevalence and diagnostic accuracy, Cerebrovasc. Dis., 2000, 10: 380-6.

33. KELLER H.H., Malnutrition in institutionalized elderly: how and why?, J. Am. Geriatr. Soc., 1993, 41: $1212-8$.

34. EDWARDS L.L., QUIGLEY E.M., PFEIFFER R.F., Gastrointestinal dysfunction in Parkinson's disease: frequency and pathophysiology, Neurology, 1992, 42: 726-32.

35. PARKER B.A., CHAPMAN I.M., Food intake and ageing - the role of the gut, Mech. Ageing. Dev., 2004, 125: 859-66.

36. WILSON M.M., VASWANI S., LIU D., MORLEY J.E., MILLER D.K., Prevalence and causes of undernutrition in medical outpatients, Am. J. Med., 1998, 104: 56-63.

37. RABINOVITZ M., PITLIK S.D., LEIFER M., GARTY M., ROSENFELD J.B., Unintentional weight loss. A retrospective analysis of 154 cases, Arch. Intern. Med., 1986, 146: 186-7.

38. DE CASTRO J.M., BREWER E.M., The amount eaten in meals by humans is a power function of the number of people present, Physiol. Behav., 1992, 51: 121-5.

39. LOCHER J.L., ROBINSON C.O., ROTH D.L., RITCHIE C.S., BURGIO K.L., The effect of the presence of others on caloric intake in homebound older adults, J. Gerontol. A Biol. Sci. Med. Sci., 2005, 60: 1475-8.

40. KUCZMARSKI M.F., WEDDLE D.O., AMERICAN DIETETIC A., Position paper of the American Dietetic Association: nutrition across the spectrum of aging, J. Am. Diet. Assoc., 2005, 105: 616-33.

41. DONINI L.M., POGGIOGAlle E., PIREDDA M., PINTO A., BARBAGAllO M., CUCINOTTA D. et al., Anorexia and eating patterns in the elderly, PLoS One, 2013, 8: e63539. 
42. ENGEL J.H., SIEWERDT F., JACKSON R., AKOBUNDU U., WAIT C., SAHYOUN N., Hardiness, depression, and emotional well-being and their association with appetite in older adults, J. Am. Geriatr. Soc., 2011, 59: 482-7.

43. EVANS W.J., MORLEY J.E., ARGILES J., BALES C., BARACOS V., GUTTRIDGE D. et al., Cachexia: a new definition, Clin. Nutr., 2008, 27: 793-9.

44. MARTINEZ M., ARNALICH F., HERNANZ A., Alterations of anorectic cytokine levels from plasma and cerebrospinal fluid in idiopathic senile anorexia, Mech. Ageing Dev., 1993, 72: 145-53.

45. OLDENBURG H.S., ROGY M.A., LAZARUS D.D., VAN ZEE K.J., KEELER B.P., CHIZZONITE R.A. et al., Cachexia and the acute-phase protein response in inflammation are regulated by interleukin-6, Eur. J. Immunol., 1993, 23: $1889-94$.

46. ROUBENOFF R., HARRIS T.B., ABAD L.W., WILSON P.W., DALlAL G.E., DINARELlO C.A., Monocyte cytokine production in an elderly population: effect of age and inflammation, J. Gerontol. A Biol. Sci. Med. Sci., 1998, 53: M20-6.

47. ALI S., GARCIA J.M., Sarcopenia, cachexia and aging: diagnosis, mechanisms and therapeutic options - a mini-review, Gerontology, 2014, 60: 294-305.

48. JANSSEN I., The epidemiology of sarcopenia, Clin. Geriatr. Med., 2011, 27: 355-63.

49. CRUZ-JENTOFT A.J., BAEYENS J.P., BAUER J.M., BOIRIE Y., CEDERHOLM T., LANDI F. et al., Sarcopenia: European consensus on definition and diagnosis: Report of the European Working Group on Sarcopenia in Older People, Age Ageing, 2010, 39: 412-23.

50. ROUBENOFF R., Origins and clinical relevance of sarcopenia, Can. J. Appl. Physiol., 2001, 26: 78-89.

51. RASMUSSEN B.B., FUJITA S., WOLFE R.R., MITTENDORFER B., ROY M., ROWE V.L. et al., Insulin resistance of muscle protein metabolism in aging, FASEB J., 2006, 20: 768-9.

52. KYLE U.G., MORABIA A., SCHUTZ Y., PICHARD C., Sedentarism affects body fat mass index and fat-free mass index in adults aged 18 to 98 years, Nutrition, 2004, 20: 255-60.

53. RANTANEN T., ERA P., HEIKKINEN E., Physical activity and the changes in maximal isometric strength in men and women from the age of 75 to 80 years, J. Am. Geriatr. Soc., 1997, 45: 1439-45.

54. HOUSTON D.K., TOOZE J.A., GARCIA K., VISSER M., RUBIN S., HARRIS T.B. et al., Protein Intake and Mobility Limitation in Community-Dwelling Older Adults: the Health ABC Study, J. Am. Geriatr. Soc., 2017, 65: 1705-1711.

55. LINDLE R.S., METTER E.J., LYNCH N.A., FLEG J.L., FOZARD J.L., TOBIN J. et al., Age and gender comparisons of muscle strength in 654 women and men aged 20-93 yr, J. Appl. Physiol. (1985), 1997, 83: 1581-7.

56. VECCHIE A., DALLEGRI F., CARBONE F., BONAVENTURA A., LIBERALE L., PORTINCASA P. et al., Obesity phenotypes and their paradoxical association with cardiovascular diseases, Eur. J. Intern. Med., 2018, 48: 6-17.

57. US Department of Health Human Services. Helping patients who drink too much: a clinician's guide, National Institutes of Health, National Institute on Alcohol Abuse and Alcoholism, NIH Publication, 2005: 07-3769.

58. MAYFIELD D., MCLEOD G., HALL P., The CAGE questionnaire: validation of a new alcoholism screening instrument, Am. J. Psychiatry, 1974, 131: 1121-3.

59. GNANADESIGAN N., FUNG C.H., Quality indicators for screening and prevention in vulnerable elders, J. Am. Geriatr. Soc., 2007, 55(2): S417-23.

60. WILSON S.R., KNOWLES S.B., HUANG Q., FINK A., The prevalence of harmful and hazardous alcohol consumption in older U.S. adults: data from the 2005-2008 National Health and Nutrition Examination Survey (NHANES), J. Gen. Intern. Med., 2014, 29: 312-9.

61. WHITE J.V., GUENTER P., JENSEN G., MALONE A., SCHOFIELD M., Academy Malnutrition Work, Group. A.S.P.E.N. Malnutrition Task Force. A.S.P.E.N. Board of Directors. Consensus statement: Academy of Nutrition and Dietetics and American Society for Parenteral and Enteral Nutrition: characteristics recommended for the identification and documentation of adult malnutrition (undernutrition), JPEN J. Parenter. Enteral. Nutr., 2012, 36: 275-83.

62. JENSEN G.L., CEDERHOLM T., CORREIA M., GONZALEZ M.C., FUKUSHIMA R., HIGASHIGUCHI T. et al., GLIM Criteria for the Diagnosis of Malnutrition: A Consensus Report From the Global Clinical Nutrition Community, JPEN J. Parenter. Enteral. Nutr., 2019, 43: 32-40.

63. ULIJASZEK S.J., KERR D.A., Anthropometric measurement error and the assessment of nutritional status, Br. J. Nutr., 1999, 82: $165-77$.

64. GREGG E.W., GERZOFF R.B., THOMPSON T.J., WILLIAMSON D.F., Intentional weight loss and death in overweight and obese U.S. adults 35 years of age and older, Ann. Intern. Med., 2003, 138: 383-9.

65. WANNAMETHEE S.G., SHAPER A.G., LENNON L., Reasons for intentional weight loss, unintentional weight loss, and mortality in older men, Arch. Intern. Med., 2005, 165: 1035-40.

66. NEWMAN A.B., YANEZ D., HARRIS T., DUXBURY A., ENRIGHT P.L., FRIED L.P. et al., Weight change in old age and its association with mortality, J. Am. Geriatr. Soc., 2001, 49: 1309-18.

67. ZAWADA E.T. Jr., Malnutrition in the elderly. Is it simply a matter of not eating enough?, Postgrad. Med., 1996, 100: 207-8, 211-4, 220-2 passim.

68. Health Care Financing Administration. Long Term Care Facility Resident Assessment (RAI) User's Manual, Minimum Data Set, Natick, MA, Eliot Press, 1999.

69. HERNANDEZ J.L., RIANCHO J.A., MATORRAS P., GONZALEZ-MACIAS J., Clinical evaluation for cancer in patients with involuntary weight loss without specific symptoms, Am. J. Med., 2003, 114: 631-7.

70. National Institutes of Health (NIH), National Heart, Lung, and Blood Institute (NHLBI), The practical guide: identification, evaluation, and treatment of overweight and obesity in adults, 2000 Bethesda: National Institutes of Health.

71. LOCHER J.L., ROTH D.L., RITCHIE C.S., COX K., SAWYER P., BODNER E.V. et al., Body mass index, weight loss, and mortality in community-dwelling older adults, J. Gerontol. A Biol. Sci. Med. Sci., 2007, 62: 1389-92.

72. CHANG S.H., BEASON T.S., HUNLETH J.M., COLDITZ G.A., A systematic review of body fat distribution and mortality in older people, Maturitas, 2012, 72: 175-91. 
73. VILLAREAL D.T., CHODE S., PARIMI N., SINACORE D.R., HILTON T., ARMAMENTO-VILLAREAL R. et al., Weight loss, exercise, or both and physical function in obese older adults, N. Engl. J. Med., 2011, 364: 1218-29.

74. SHEA M.K., HOUSTON D.K., NICKLAS B.J., MESSIER S.P., DAVIS C.C., MILLER M.E. et al., The effect of randomization to weight loss on total mortality in older overweight and obese adults: the ADAPT Study, J. Gerontol. A Biol. Sci. Med. Sci., 2010, 65: 519-25.

75. BALES C.W., BUHR G., Is obesity bad for older persons? A systematic review of the pros and cons of weight reduction in later life, J. Am. Med. Dir. Assoc., 2008, 9: 302-12.

76. DE HOLLANDER E.L., BEMELMANS W.J., BOSHUIZEN H.C., FRIEDRICH N., WALLASCHOFSKI H., GUALLARCASTILLON P. et al., The association between waist circumference and risk of mortality considering body mass index in 65- to 74-year-olds: a meta-analysis of 29 cohorts involving more than 58000 elderly persons, Int. J. Epidemiol., 2012, 41: 805-17.

77. BHARADWAJ S., GINOYA S., TANDON P., GOHEL T.D., GUIRGUIS J., VALLABH H. et al., Malnutrition: laboratory markers vs nutritional assessment, Gastroenterol. Rep. (Oxf), 2016, 4: 272-280.

78. FORSE R.A., SHIZGAL H.M., The assessment of malnutrition, Surgery, 1980, 88: 17-24.

79. BOUILLANNE O., MORINEAU G., DUPONT C., COULOMBEL I., VINCENT J.P., NICOLIS I. et al., Geriatric Nutritional Risk Index: a new index for evaluating at-risk elderly medical patients, Am. J. Clin. Nutr., 2005, 82: 777-83.

80. ELIA M., STRATTON R.J., An analytic appraisal of nutrition screening tools supported by original data with particular reference to age, Nutrition, 2012, 28: 477-94.

81. STRATTON R.J., HACKSTON A., LONGMORE D., DIXON R., PRICE S., STROUD M. et al., Malnutrition in hospital outpatients and inpatients: prevalence, concurrent validity and ease of use of the 'malnutrition universal screening tool' ('MUST') for adults, Br. J. Nutr., 2004, 92: 799-808.

82. KONDRUP J., ALLISON S.P., ELIA M., VELLAS B., PLAUTH M., EDUCATIONAL et al., ESPEN guidelines for nutrition screening 2002, Clin. Nutr., 2003, 22: 415-21.

83. FERGUSON M., CAPRA S., BAUER J., BANKS M., Development of a valid and reliable malnutrition screening tool for adult acute hospital patients, Nutrition, 1999, 15: 458-64.

84. CHARLTON K.E., KOLBE-ALEXANDER T.L., NEL J.H., The MNA, but not the DETERMINE, screening tool is a valid indicator of nutritional status in elderly Africans, Nutrition, 2007, 23: 533-42.

85. SIEBER C.C., Nutritional screening tools - How does the MNA compare? Proceedings of the session held in Chicago May 2-3, 2006 (15 Years of Mini Nutritional Assessment), J. Nutr. Health Aging, 2006, 10: 488-92, discussion 492-4.

86. VELLAS B., GUIGOZ Y., GARRY P.J., NOURHASHEMI F., BENNAHUM D., LAUQUE S. et al., The Mini Nutritional Assessment (MNA) and its use in grading the nutritional state of elderly patients, Nutrition, 1999, 15: 116-22.

87. VELLAS B., VILLARS H., ABELLAN G., SOTO M.E., ROLLAND Y., GUIGOZ Y. et al., Overview of the MNA - Its history and challenges, J. Nutr. Health Aging, 2006, 10: 456-63, discussion 463-5.

88. KAISER M.J., BAUER J.M., RAMSCH C., UTER W., GUIGOZ Y., CEDERHOLM T. et al., Validation of the Mini Nutritional Assessment short-form (MNA-SF): a practical tool for identification of nutritional status, J. Nutr. Health Aging, 2009, 13: 782-8.

89. GUIGOZ Y., The Mini Nutritional Assessment (MNA) review of the literature - What does it tell us?, J. Nutr. Health Aging, 2006, 10: 466-85, discussion 485-7.

90. GUIGOZ Y., LAUQUE S., VELLAS B.J., Identifying the elderly at risk for malnutrition. The Mini Nutritional Assessment, Clin. Geriatr. Med., 2002, 18: 737-57.

91. RUBENSTEIN L.Z., HARKER J.O., SALVA A., GUIGOZ Y., VELLAS B., Screening for undernutrition in geriatric practice: developing the short-form mini-nutritional assessment (MNA-SF), J. Gerontol. A Biol. Sci. Med. Sci., 2001, 56: M366-72.

92. RENTERO REDONDO L., INIESTA NAVALON C., GASCON CANOVAS J.J., TOMAS JIMENEZ C., SANCHEZ ALVAREZ C., [Malnutrition in the Elderly Patient to Hospital Admission, an Old Problem Unsolved], Nutr. Hosp., 2015, 32: 2169-77.

93. BLEDA M.J., BOLIBAR I., PARES R., SALVA A., Reliability of the mini nutritional assessment (MNA) in institutionalized elderly people, J. Nutr. Health Aging, 2002, 6: 134-7.

94. KYLE U.G., GENTON L., PICHARD C., Hospital length of stay and nutritional status, Curr. Opin. Clin. Nutr. Metab. Care., 2005, 8: 397-402.

95. QUADRI P., FRAGIACOMO C., PERTOLDI W., GUIGOZ Y., HERRMANN F., RAPIN C.H., MNA and cost of care, Nestle Nutr. Workshop Ser. Clin. Perform. Programme, 1999, 1: 141-7, discussion 148.

96. RUIZ-LOPEZ M.D., ARTACHO R., OLIVA P., MORENO-TORRES R., BOLANOS J., DE TERESA C. et al., Nutritional risk in institutionalized older women determined by the Mini Nutritional Assessment test: what are the main factors?, Nutrition, 2003, 19: 767-71.

97. VISVANATHAN R., PENHALL R., CHAPMAN I., Nutritional screening of older people in a sub-acute care facility in Australia and its relation to discharge outcomes, Age Ageing, 2004, 33: 260-5.

98. HYUN HS, LEE I., [Nutritional status and risk factors for malnutrition in low-income urban elders], J. Korean Acad. Nurs., 2014, 44: 708-16.

99. DONINI L.M., SAVINA C., ROSANO A., DE FELICE M.R., TASSI L., DE BERNARDINI L. et al., MNA predictive value in the follow-up of geriatric patients, J. Nutr. Health Aging, 2003, 7: 282-93.

100. SAAVA M., KISPER-HINT I.R., Nutritional assessment of elderly people in nursing house and at home in Tallinn, J. Nutr. Health Aging, 2002, 6: 93-5.

101. TSAI A.C., CHANG J.M., LIN H., CHUANG Y.L., LIN S.H., LIN Y.H., Assessment of the nutritional risk of $>53-y e a r-o l d$ men and women in Taiwan, Public Health Nutr., 2004, 7: 69-76.

102. SOINI H., ROUTASALO P., LAGSTROM H., Characteristics of the Mini-Nutritional Assessment in elderly home-care patients, Eur. J. Clin. Nutr., 2004, 58: 64-70. 
103. KUZUYA M., KANDA S., KOIKE T., SUZUKI Y., SATAKE S., IGUCHI A., Evaluation of Mini-Nutritional Assessment for Japanese frail elderly, Nutrition, 2005, 21: 498-503.

104. URTEAGA C., RAMOS R.I., ATALAH E., [Validation of global nutrition assessment in elders], Rev. Med. Chil., 2001, 129: $871-6$.

105. ALVES DE REZENDE C.H., MARQUEZ CUNHA T., ALVARENGA JUNIOR V., PENHA-SILVA N., Dependence of MiniNutritional Assessment scores with age and some hematological variables in elderly institutionalized patients, Gerontology, 2005, 51: 316-21.

106. PERSSON M.D., BRISMAR K.E., KATZARSKI K.S., NORDENSTROM J., CEDERHOLM T.E., Nutritional status using mini nutritional assessment and subjective global assessment predict mortality in geriatric patients, J. Am. Geriatr. Soc., 2002, 50: 1996-2002.

107. VOLKERT D., BERNER Y.N., BERRY E., CEDERHOLM T., COTI BERTRAND P., MILNE A. et al., ESPEN Guidelines on Enteral Nutrition: Geriatrics, Clin. Nutr., 2006, 25: 330-60.

108. THOMAS D.R., ASHMEN W., MORLEY J.E., EVANS W.J., Nutritional management in long-term care: development of a clinical guideline. Council for Nutritional Strategies in Long-Term Care, J. Gerontol. A Biol. Sci. Med. Sci., 2000, 55: M725-34.

109. LICHTENSTEIN A.H., RASMUSSEN H., YU W.W., EPSTEIN S.R., RUSSELL R.M., Modified MyPyramid for Older Adults, J. Nutr., 2008, 138: 5-11.

110. BECK A.M., DENT E., BALDWIN C., Nutritional intervention as part of functional rehabilitation in older people with reduced functional ability: a systematic review and meta-analysis of randomised controlled studies, J. Hum. Nutr. Diet., 2016, 29: 733-745.

111. MORLEY J.E., Anorexia of aging: physiologic and pathologic, The American journal of clinical nutrition, 1997, 66: 760-773.

112. TRUMBO P., SCHLICKER S., YATES A.A., POOS M., FOOD, NUTRITION BOARD OF THE INSTITUTE OF MEDICINE TNA. Dietary reference intakes for energy, carbohydrate, fiber, fat, fatty acids, cholesterol, protein and amino acids, J. Am. Diet. Assoc., 2002, 102: 1621-30.

113. BUCKLER D.A., KELBER S.T., GOODWIN J.S., The use of dietary restrictions in malnourished nursing home patients, J. Am. Geriatr. Soc., 1994, 42: 1100-2.

114. SIMMONS S.F., KEELER E., ZHUO X., HICKEY K.A., SATO H.W., SCHNELLE J.F., Prevention of unintentional weight loss in nursing home residents: a controlled trial of feeding assistance, J. Am. Geriatr. Soc., 2008, 56: 1466-73.

115. MITCHELL S.L., KIELY D.K., LIPSITZ L.A., The risk factors and impact on survival of feeding tube placement in nursing home residents with severe cognitive impairment, Arch. Intern. Med., 1997, 157: 327-32.

116. MITCHELL S.L., KIELY D.K., LIPSITZ L.A., Does artificial enteral nutrition prolong the survival of institutionalized elders with chewing and swallowing problems?, J. Gerontol. A Biol. Sci. Med. Sci., 1998, 53: M207-13.

117. DORNER B., POSTHAUER M.E., THOMAS D., NATIONAL PRESSURE ULCER ADVISORY P. The role of nutrition in pressure ulcer prevention and treatment: National Pressure Ulcer Advisory Panel white paper, Adv. Skin. Wound. Care., 2009, 22: $212-21$.

118. STRATTON R.J., EK A.C., ENGFER M., MOORE Z., RIGBY P., WOLFE R. et al., Enteral nutritional support in prevention and treatment of pressure ulcers: a systematic review and meta-analysis, Ageing Res. Rev., 2005, 4: 422-50.

119. SUKKAR S.G., GALLO F., BORRINI C., VACCARO A., MARCHELLO C., BOICELLI R. et al., Effects of a new mixture of essential amino acids (Aminotrofic((R))) in malnourished haemodialysis patients, Med. J. Nutrition Metab., 2012, 5: $259-266$.

120. SOLERTE S.B., GAZZARUSO C., SCHIFINO N., LOCATELLI E., DESTRO T., CERESINI G. et al., Metabolic effects of orally administered amino acid mixture in elderly subjects with poorly controlled type 2 diabetes mellitus, Am. J. Cardiol., 2004, 93: 23A-29A.

121. PASINI E., OPASICH C., PASTORIS O., AQUILANI R., Inadequate nutritional intake for daily life activity of clinically stable patients with chronic heart failure, Am. J. Cardiol., 2004, 93: 41A-43A.

122. VAN KOEVERING M., NISSEN S., Oxidation of leucine and alpha-ketoisocaproate to beta-hydroxy-beta-methylbutyrate in vivo, Am. J. Physiol., 1992, 262: E27-31.

123. MOLFINO A., GIOIA G., ROSSI FANELLI F., MUSCARITOLI M., Beta-hydroxy-beta-methylbutyrate supplementation in health and disease: a systematic review of randomized trials, Amino Acids, 2013, 45: 1273-92.

124. WU H., XIA Y., JIANG J., DU H., GUO X., LIU X. et al., Effect of beta-hydroxy-beta-methylbutyrate supplementation on muscle loss in older adults: a systematic review and meta-analysis, Arch. Gerontol. Geriatr., 2015, 61: 168-75.

125. RIEU I., BALAGE M., SORNET C., GIRAUDET C., PUJOS E., GRIZARD J. et al., Leucine supplementation improves muscle protein synthesis in elderly men independently of hyperaminoacidaemia, J. Physiol., 2006, 575: 305-15.

126. DEUTZ N.E., PEREIRA S.L., HAYS N.P., OLIVER J.S., EDENS N.K., EVANS C.M. et al., Effect of beta-hydroxy-betamethylbutyrate (HMB) on lean body mass during 10 days of bed rest in older adults, Clin. Nutr., 2013, 32: 704-12.

127. HUISMAN M., VERONESE G., AUDISIO R., UGOLINI G., MONTRONI I., DE BOCK G. et al., Poor nutritional status is associated with other geriatric domain impairments and adverse postoperative outcomes in onco-geriatric surgical patients - $A$ multicentre cohort study, European Journal of Surgical Oncology (EJSO), 2016, 42: 1009-1017.

128. PETERSON S.J., BRAUNSCHWEIG C.A., Prevalence of sarcopenia and associated outcomes in the clinical setting, Nutrition in Clinical Practice, 2016, 31: 40-48.

129. FRIEDMANN J.M., JENSEN G.L., SMICIKLAS-WRIGHT H., MCCAMISH M.A., Predicting early nonelective hospital readmission in nutritionally compromised older adults, The American journal of clinical nutrition, 1997, 65: 1714-1720.

130. FLODIN L., CEDERHOLM T., SÄÄF M., SAMNEGÅRD E., EKSTRÖM W., AL-ANI A.N. et al., Effects of protein-rich nutritional supplementation and bisphosphonates on body composition, handgrip strength and health-related quality of life after hip fracture: a 12-month randomized controlled study, BMC geriatrics, 2015, 15: 149.

131. SULLIVAN D.H., WALLS R.C., BOPP M.M., Protein-energy undernutrition and the risk of mortality within one year of hospital discharge: A follow-up study, Journal of the American Geriatrics Society, 1995, 43: 507-512. 
132. SULLIVAN D.H., PATCH G.A., WALLS R., LIPSCHITZ D., Impact of nutrition status on morbidity and mortality in a select population of geriatric rehabilitation patients, The American journal of clinical nutrition, 1990, 51: 749-758.

133. RUSSELL C.A., The impact of malnutrition on healthcare costs and economic considerations for the use of oral nutritional supplements, Clinical Nutrition Supplements, 2007, 2: 25-32.

134. LJUNGQVIST O., VAN GOSSUM A., SANZ M.L., DE MAN F., The European fight against malnutrition, Clinical Nutrition, 2010, 29: 149-150.

135. STRATTON R.J., ELIA M., A review of reviews: a new look at the evidence for oral nutritional supplements in clinical practice, Clinical Nutrition Supplements, 2007, 2: 5-23.

136. VERONESE N., STUBBS B., PUNZI L., SOYSAL P., INCALZI R.A., SALlER A. et al., Effect of nutritional supplementations on physical performance and muscle strength parameters in older people: A systematic review and metaanalysis, Ageing Res. Rev., 2019, 51: 48-54.

137. MILNE A.C., AVENELL A., POTTER J., Meta-analysis: protein and energy supplementation in older people., Ann. Intern. Med., 2006, 144: 37-48.

138. RONDANELLI M., OPIZZI A., ANTONIELLO N., BOSCHI F., IADAROLA P., PASINI E. et al., Effect of essential amino acid supplementation on quality of life, amino acid profile and strength in institutionalized elderly patients, Clin. Nutr., 2011, 30: $571-7$.

139. SOLERTE S.B., GAZZARUSO C., BONACASA R., RONDANELLI M., ZAMBONI M., BASSO C. et al., Nutritional supplements with oral amino acid mixtures increases whole-body lean mass and insulin sensitivity in elderly subjects with sarcopenia, Am. J. Cardiol., 2008, 101: 69E-77E.

140. PASCUAL LOPEZ A., ROQUE I FIGULS M., URRUTIA CUCHI G., BERENSTEIN E.G., ALMENAR PASIES B., BALCELLS ALEGRE M. et al., Systematic review of megestrol acetate in the treatment of anorexia-cachexia syndrome, J. Pain. Symptom. Manage., 2004; 27: 360-9.

141. BERENSTEIN E.G., ORTIZ Z., Megestrol acetate for the treatment of anorexia-cachexia syndrome, Cochrane Database Syst. Rev., 2005: CD004310.

142. RUIZ GARCIA V., LOPEZ-BRIZ E., CARBONELL SANCHIS R., GONZALVEZ PERALES J.L., BORT-MARTI S., Megestrol acetate for treatment of anorexia-cachexia syndrome, Cochrane Database Syst. Rev., 2013: CD004310.

143. BEAL J.E., OLSON R., LAUBENSTEIN L., MORALES J.O., BELLMAN P., YANGCO B. et al., Dronabinol as a treatment for anorexia associated with weight loss in patients with AIDS, J. Pain. Symptom. Manage., 1995, 10: 89-97.

144. SEGERS K., SURQUIN M., Can mirtazapine counteract the weight loss associated with Alzheimer disease? A retrospective open-label study, Alzheimer Dis. Assoc. Disord., 2014, 28: 291-3.

145. NASS R., PEZZOLI S.S., OLIVERI M.C., PATRIE J.T., HARRELL F.E. Jr., CLASEY J.L. et al., Effects of an oral ghrelin mimetic on body composition and clinical outcomes in healthy older adults: a randomized trial, Ann. Intern. Med., 2008, 149: 601-11.

Received January $22^{\text {nd }} 2020$ 